https://doi.org/10.15407/scine17.01.078

KOVALETS, I.V. ', MAISTRENKO, S.Ya. ', KHALCHENKOV, O.V. ', POLONSKY, O.O.?, DONTSOV-ZAGREBA, T.O.', KHURTSILAVA, K.V. ${ }^{1}$, and UDOVENKO, O.I. ${ }^{2}$

'Institute of Mathematical Machines and Systems Problems, the NAS of Ukraine, 42, prosp. Glushkova, Kyiv, 03187, Ukraine,

+380445263615, ik@env.com.ua

${ }^{2}$ Ukrainian Center of Environmental and Water Projects,

42, prosp. Glushkova, Kyiv, 03187, Ukraine,

+38044526 4578, If@env.kiev.ua

\title{
ADAPTATION OF THE WEB-SERVICE OF AIR POLLUTION FORECASTING FOR OPERATION WITHIN CLOUD COMPUTING PLATFORM OF THE UKRAINIAN NATIONAL GRID INFRASTRUCTURE
}

Introduction. Air pollution modeling is a powerful tool that allows developing scientifically justified solutions to reduce the risks posed by atmospheric emissions of pollutants.

Problem Statement. Cloud computing infrastructures provide new opportunities for web-based air pollution forecasting systems. However the implementation of these capabilities requires changes in the architecture of the existing systems.

Purpose. The purpose is to adapt the web service of forecasting the atmospheric pollution in Ukraine to operate in the cloud computing platform of the Ukrainian National Grid infrastructure.

Materials and Methods. The web client - web server - cloud computing architecture was used. The calculation of the model is performed in the cloud infrastructure, while the client and server parts operate on separate computers.

Results. With the developed service the forecast of air pollution is possible for every point at the territory of Ukraine for more than thirty substances, including chlorine, ammonia, hydrogen sulfide and others. The forecast is performed using the data of the WRF-Ukraine numerical weather prediction system and visualized through a web interface. The capabilities of the developed system were demonstrated by the example of simulation of air pollution in part of Kyiv affected by the releases from the Energia incineration plant during pollution episode in September, 2019. The total releases of toluene gas from incineration plant and from the fire on spontaneous waste landfill, which is located a few $\mathrm{km}$ from Kyiv, were estimated and analyzed. For the considered period the fire could bring considerable additional amounts of pollutants to the studied region. The confidence interval for the

Citation: Kovalets I.V., Maistrenko S.Ya., Khalchenkov O.V., Polonsky O.O., Dontsov-Zagreba T.O., Khurtsilava K.V., and Udovenko O.I. Adaptation of the Web-Service of Air Pollution Forecasting for Operation within Cloud Computing Platform of the Ukrainian National Grid Infrastructure. Sci. innov. 2021. V. 17, no. 1. P. 78-88. https://doi.org/10.15407/scine17.01.078 
maximum airborne concentration for the considered period is estimated from 0.7 to $2.1 \mathrm{mg} \cdot \mathrm{m}^{-3}$ which is higher than the permissible value $\left(0.6 \mathrm{mg} \cdot \mathrm{m}^{-3}\right)$.

Conclusions. The presented system could be used by institutions responsible for response to environmental accidents.

Keywords: air pollution, atmospheric dispersion, web-systems, cloud computing.

Air pollution modeling is a powerful tool that allows operational assessment of the spatial and temporal distribution of pollutants following accidental and routine releases to the atmosphere. The range of users of air pollution modeling tools is not limited to meteorologists but includes many other professionals such as civil engineers, managers in emergency preparedness, environmental managers, and many others. Examples of applications of air pollution models are numerous and include, but not limited to studies of urban air quality [1, 2], air pollution created by wildfires and dust storms [3, 4], simulation of pollution following accidental releases of toxic chemicals and radionuclides [5, 6]. Therefore several webbased applications appeared which allow access to air pollution models for a wide range of interested users. For example, the system [7] allows users all over the world to run a famous HYSPLIT model using a web interface. The Povitrya similar web-based system has been developed by the authors of the present work [8]. It allows users to perform calculations of air pollution following accidental releases at the territory of Ukraine using the CALPUFF model [9]. The calculations are driven by numerical weather prediction data generated by the mesoscale meteorological model WRF [10] operated within WRF-Ukraine numerical weather prediction system [11]. Usually existing web-based air pollution forecasting systems use traditional client-server architecture. The calculations, initialized by the user, are carried out at the dedicated computational server. Such architecture does not allow increasing the number of simultaneously performed calculations because the number of computational cores is restricted. At the same time modern cloud computing infrastructures such as European Open Science Cloud (EOSC) (www.eosc-portal.eu), Amazon Cloud Computing
Services (https://aws.amazon.com/), and others possess great potential for increasing the number of simultaneous calculations by using virtual machines. However this requires the redesign of the original client-server architecture of the system to include cloud computing infrastructure and corresponding implementation. Thus the goal of the present work is to redesign the created earlier web-service of air pollution forecasting to enable usage of the resources of the Cloud computing platform of the Ukrainian National Grid Infrastructure (UNG) [12].

\section{Architecture and implementation of the forecasting system in the cloud infrastructure}

To ensure a simple and effective process for forecasting atmospheric pollution, the (web-client)(web-server)-(cloud computing) architecture was chosen. Schematically, the system architecture is shown in the Fig.1. In this implementation, the client and server parts operate on computers that are not part of the cloud infrastructure. In the current implementation, a computer with the following characteristics is used to host the server part: two physical Intel Xeon E5335 @ 2.00GHz processors, 4 cores each, 16 gigabytes of RAM, 1 terabyte hard drive.

To program interaction with a remote server using the SSH (Secure Shell) protocol, the JSch Java library is used. SSH protocol combines three levels of protocols: authentication protocol (The Secure Shell Authentication Protocol, RFC 4252); transport layer protocol (The Secure Shell Transport Layer Protocol, RFC 4253), which provides algorithm interaction and key exchange; connection protocol (The Secure Shell Connection Protocol, RFC 4254), which creates a secure (encrypted) channel. SSH support is implemented on all 


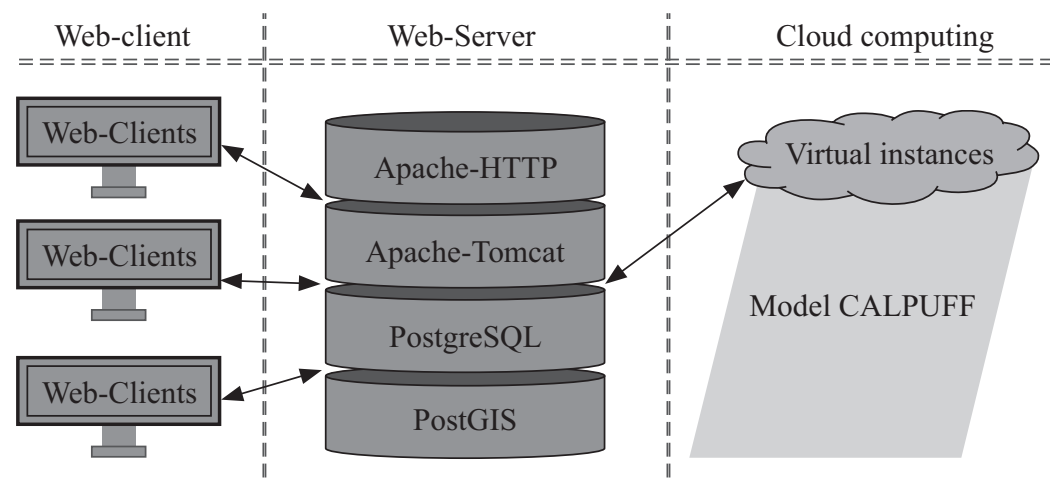

Fig. 1. Cloud Computing Web Service Architecture

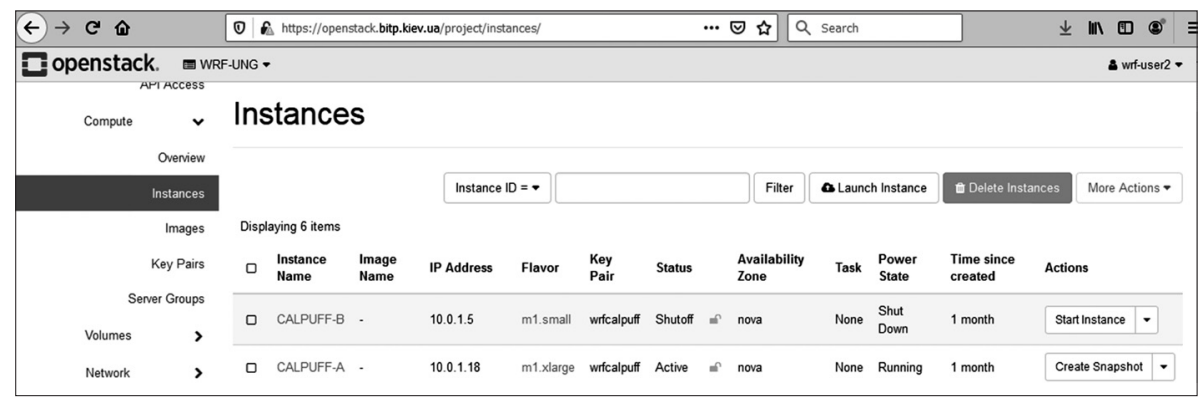

Fig. 2. Working instances created in the UNG cloud platform and designed to run atmospheric transport models

UNIX systems, and in most of them both client and server software is included in a typical delivery. Thus, the SSH connection provides reliable authentication, encryption, and data integrity to combat cracking passwords and other security threats.

Calculations of atmospheric pollution are performed using the CALPUFF model [9] in the cloud platform of the Ukrainian National Grid infrastructure (http://ung.in.ua, see also [12]). The UNG base coordination center serves as the National Operational Center (Resource infrastructure Provider) of UNG grid resources at the technological and operational level in relationships with the international grid communities, including the European Open Science Cloud (EOSC). Thus, the implementation of the service in the UNG cloud platform is a necessary step towards its further integration into the EOSC.

To automate the calculations, a model is used to provide convenient network access to a set of parameters for the collective use of cloud infrastructure, such as computing resources in the "ondemand" mode [13].

To run the mathematical model in the UNG cloud infrastructure, two instances were created (Fig. 2): CALPUFF-A for calculations covering large geographical areas (4 processor cores, 8 gigabytes of memory, a 200-gigabyte hard drive) and CALPUFF-B for calculations covering small areas (1 processor core, 1 gigabyte of memory, 300 hard drive).

In general, the forecasting process includes the following steps (Fig. 3).

1. The user is registered in the system, generates forecast parameters, and initiates the calculation.

2. Server service puffconf.jar.

- monitors changes in the journal of calculations for the availability of forecasts in the queue for calculation;

- generates configuration files to perform the calculation; 
- establishes a connection for interaction between the web server and the "free" virtual instance using the turnon script (Fig. 3);

- initiates the launch of a new calculation in the cloud infrastructure using the cloudrunnerjar service;

- monitors the process of completing the formation of the forecast;

- records the results of calculations in a database (DB).

3. Having received the sign of the end of the forecast formation, the user views and analyzes the forecast results on a digital map.

The turnon script checks if an instance is enabled with the name that is passed as a parameter. If this instance is turned off, it turns it on. Before switching on, a control shutdown and a pause of 10 seconds occur. The turnon script uses the OpenStack command line API, in particular, the nova command. Environment variables containing parameters for accessing the OpenStack API are located in the worf_openrc file and are initiated by including this file in the script text.

The reason why only the limited number of pre-created calculating instances was used in this work (and thus limited number of users can perform calculations simultaneously) is that at present Ukrainian cloud infrastructure does not allow accessing the instances remotely via SSH from the Web server without using the intermediate instance. This intermediate instance has to be manually pre-configured to make such access possible. When remote access is allowed, there will be no need to use intermediate instance. Then it will be possible to create an instance for every task submitted by the web client and destroy this instance when all the calculations are completed and the results are downloaded from the instance. In this way cloud calculations are supposed to work in contemporary commercial cloud infrastructures.

Forecast parameters and results are stored in the database. They can be used both for subsequent analysis and for generating parameters for new forecasts.

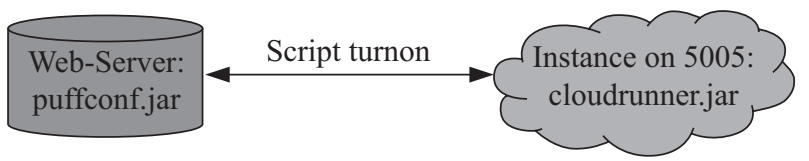

Fig. 3. Web server and virtual instance communication diagram

Performing calculations in the cloud infrastructure provide fairly rapid forecasting. So, the testing of the described web service showed that the 72 -hrs forecast for a small grid of $25 \times 25$ cells with a step of $2 \mathrm{~km}, 2$ pollution sources takes about 45 minutes, and for a grid of $100 \times 99$ cells with a step of $10 \mathrm{~km}, 10$ pollution sources it takes about 1 hour 15 minutes.

\section{Organization of atmospheric transport model calculations}

To calculate atmospheric transport, the CALMET-CALPUFF model was used [9]. This model was previously recommended by the US Environmental Protection Agency for calculations of the long-range transport of pollutants [14] and presently it remains one of the most widely used, well documented, and extensively validated atmospheric dispersion models [3, 5, 14]. The web service for forecasting weather and atmospheric pollution was implemented using the seventh (latest) version of the software products of the CALMET/CALPUFF models, which is freely available for download on the official website of the model developer (http://www.src.com).

The block diagram is shown in Fig. 4. It demonstrates the main stages of the CALPUFF model. The model includes the TERREL, CTGPROC, and MAKEGEO geographical preprocessors, the CALMET meteorological preprocessor, and the CALPUFF Lagrangian-Eulerian atmospheric transport model.

This model is implemented in the created folder structure with subprograms, in which the paths between intermediate input and output files are hard-coded. To carry out atmospheric transport modeling, the following programs must be sequentially executed: 


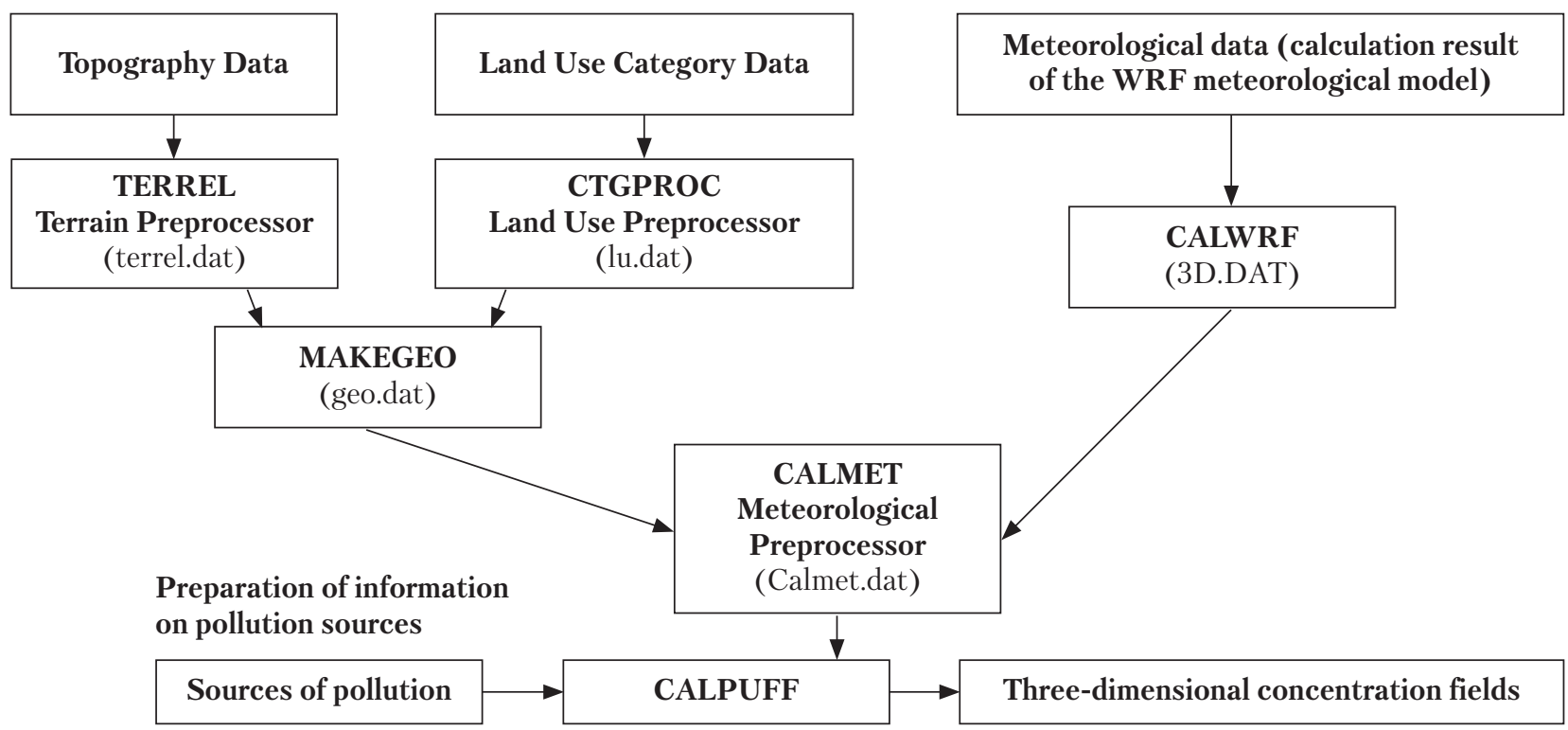

Fig. 4. Flowchart of the operation of the CALPUFF model

- terrel.exe - interpolation of topographic data on the computational grid;

- ctgproc.exe - interpolation of land use category data on the computational grid;

- makegeo.exe - summarizing all data on the underlying surface and calculating additional necessary characteristics, such as roughness parameter, albedo, etc;

- calworf.exe - converting the output file of the forecast weather model WRF into the input file of the meteorological model CALMET;

- calmet.exe - interpolation and calculation of meteorological fields on the computational grid of the atmospheric transport model;

- calpuff.exe - calculation of pollution transport;

- calpost.exe - formation of various integral and instantaneous concentration characteristics.

The meteorological forecasting system WRFUkraine [11] performs its calculation on a computational grid with latitude-longitude coordinate projection (lat-lon). Therefore, in the code of the calwrf program, it is necessary to add information about the possibility of using latitudelongitude projection. Since in this case no additional calculations and transformations are neces- sary, it is enough to add one line in the loop in the calwrf.f file:

if(map_proj.eq.1) then

elseif(map_proj.eq.6) then !here is new added line cmap $=$ 'LL'

else

…

endif

Information on topographic data is prepared by the terrel.exe preprocessor. This preprocessor can process several global sets containing topographic data with different spatial resolutions. If the user starts the preprocessor with the option $\mathrm{NTDF}=0$ (there is no input file), the source text file TERR.LST will contain the names of the global set of SRTM3 files. This allows users to get topographic data for the selected coordinate grid. SRTM data is available for download [15].

The ctgproc.exe preprocessor handles global land use suites. The GEN and NZGEN formats allow users to use any global sets of land use categories by creating a text file with the best spatial resolution, such as GlobCover ESA 2009 with a resolution of 300 meters (available from the Global Mapper program). For the model to work 

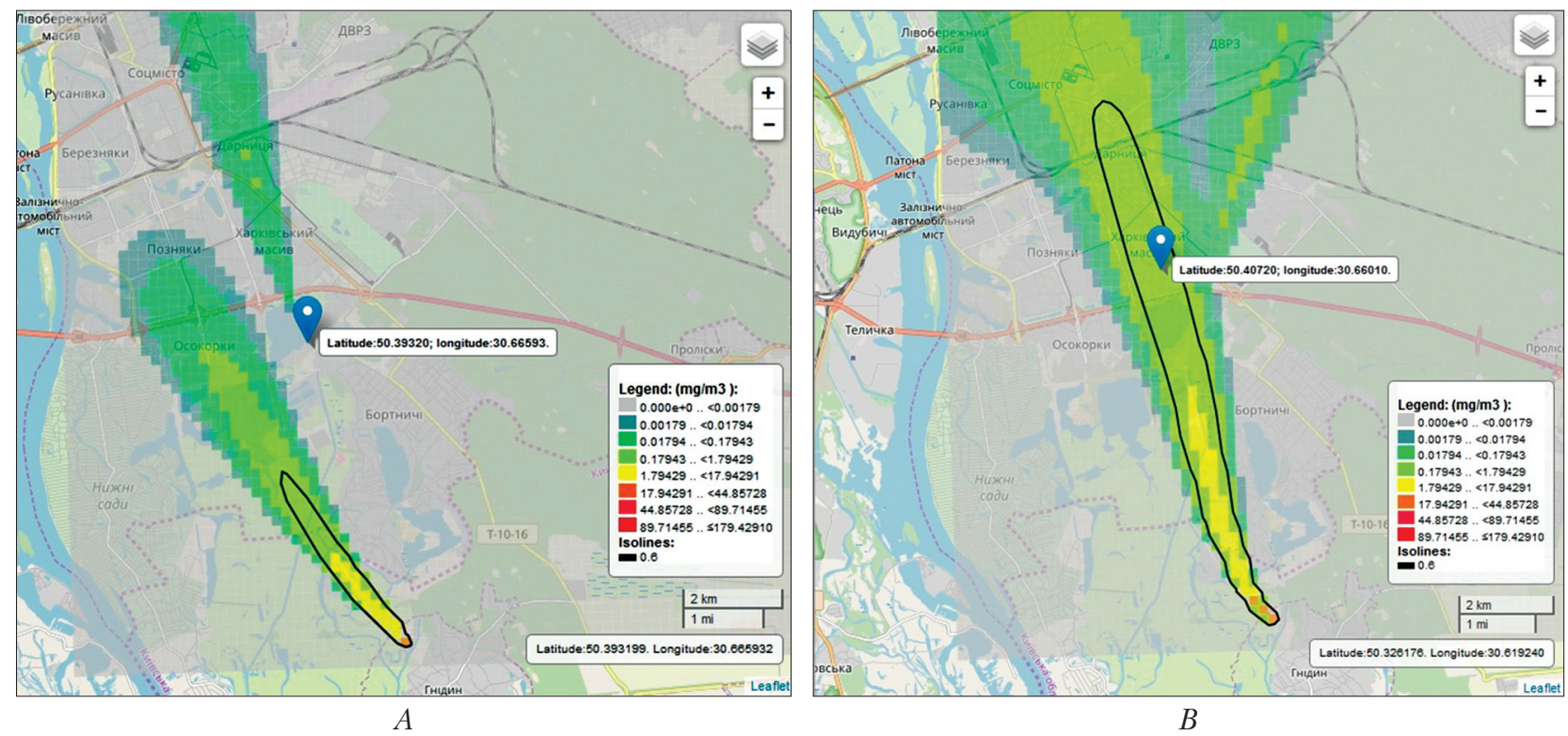

Fig. 5. Simulated instantaneous concentrations $\left[\mathrm{mg} \cdot \mathrm{m}^{-3}\right]$ of toluene following release from 'Energia' incineration plant and from spontaneous waste landfill fire near Gnidyn: $A-12$ Sept. 2019, 01 am, marker shows the location of incineration plant 'Energia'; $B$ - 12 Sept 2019, 04 am, marker shows the location of the point in Kharkivsky district at which concentration time-plot is shown in the next figure. Black isoline shows the maximum permissible limit of toluene concentration: $0.6 \mathrm{mg} \cdot \mathrm{m}^{-3}$

within the system, a file in the GeoTIFF format was created with information on topographic data, covering the entire territory of Ukraine based on the SRTM Worldwide Elevation Data set with a spatial resolution of 3 seconds. To obtain information on the land use category when working in the system, a GeoTIFF file LCType.tif [16] was also downloaded, which contains information on the land use category with a spatial resolution of 15 seconds according to the UMD Land Cover Classification (The University of Maryland Department of Geography).

\section{The functionality of the web-service and application examples}

The developed web service allows users to forecast atmospheric pollution for 72 hours based on data from the WRF-Ukraine numerical weather forecasting system [11]. The user defines a computational domain on the territory of Ukraine (coordinates of the southwest corner of the computational grid, number of cells horizontally and vertically, cell size). The information on available pollution sources is also provided by the user (coordinates and height of the source in meters; chemically hazardous substance and its quantity in $\mathrm{kg}$; date and time of the beginning of release and duration of the source). The user can select more than thirty substances, including chlorine, ammonia, hydrogen sulfide, methyl chloride, and others. By default the output concentrations are calculated in the cells of the computational grid. The user can also specify additional coordinates of point receptors for which a forecast will be generated (for example, population centers). The system provides default values for constructing concentration isolines based on certain standards: maximum single and mean daily doses.

As a result of the formation of the forecast for all sources of pollution, the concentrations, dry depositions, wet depositions, total depositions are calculated. Depending on the weather conditions, wet deposition may be absent. Also, for all types of indicators, contours can be constructed based on user-defined values. To analyze the dynamics of changes in indicators over time for the selected 


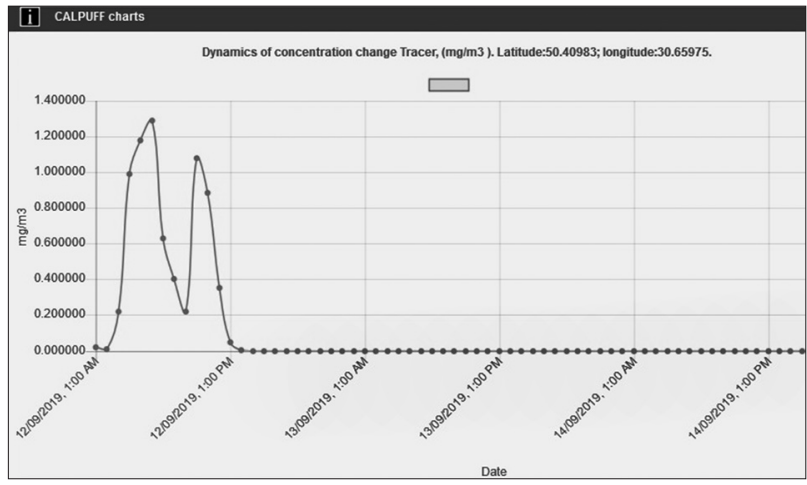

Fig. 6. Time plot of toluene concentration in the point indicated in Fig. 5

cell of the computational grid or a specific point receptor, there is the possibility of activating the time-chart.

One of the examples of applications of the developed web service is the simulation of air pollution in Kyiv during September 12-13, 2019. During that date there was raising public concern regarding odors that were especially strong at the so-called Kharkivsky District of Kyiv (Fig. 5). Unfortunately regular official monitoring of air pollution is not carried out in this region of Kyiv. Despite the absence of official measurements the public concern was caused primarily by odors and health sympthoms that were reported by many residents [17]. The Kharkivsky District is located in the zone of influence of the biggest in Ukraine incineration plant Energia [18] which processes about 700 tons of fuel per day. Therefore there was a very strong opinion among the public that the reasons for the smells could be the activity of this incineration plant. At the same time several fires on waste landfills happened near Kyiv due to very dry and hot weather. One of such fires happened on spontaneous waste landfill near Gnidyn, which is outside Kyiv but close to the studied region (Fig. 5). This obviously could influence pollution levels in nearby regions of Kyiv.

As it was shown in previous monitoring studies of Energia incineration plant, the concentrations of toluene could be especially high in exhaust gases of this plant [18]. Presumably this could happen during periods of decline in incineration temperature due to unsatisfactory calorific value and humidity of fuel. At the same time toluene could be created in large amounts during fires in waste landfills. Therefore in this work we used the presented web-system to perform simulations of airborne toluene concentrations from both sources.

The release rate of toluene from the incineration plant was set using measurements of the concentration of this pollutant in exhaust gases reported in [18] (on average 1.86, maximum $6 \mathrm{~g} \cdot \mathrm{m}^{-3}$ ). This value was multiplied by the volumetric release rate of exhaust gases $\left(70 \cdot \mathrm{m}^{3} \cdot \mathrm{s}^{-1}\right)$. The resulting average emission rate was $130 \mathrm{~g} \cdot \mathrm{s}^{-1}$ and the maximum was up to $420 \mathrm{~g} \cdot \mathrm{s}^{-1}$. In simulations we used the emission rate of toluene from Energia of $230 \mathrm{~g} \cdot \mathrm{s}^{-1}$ which is greater than the average value but less than maximum possible emission. The stack height is $120 \mathrm{~m}$, the temperature of gases at the stack output was set to $180{ }^{\circ} \mathrm{C}$ [18]. The plume rise of gases is then internally simulated by CALPUFF. In the simulation of toluene release from waste landfill fire it was assumed that concentration of toluene in exhaust gases of landfill fire is the same as in exhaust gases of the incineration plant. The area of the fire was assumed $25 \times 25 \mathrm{~m}^{2}$. The volumetric flow rate of exhaust gases created by the fire was obtained from the data in [19], who reported the flow rate of exhaust gases of $400 \mathrm{~m}^{3} \cdot \mathrm{h}^{-1}$ for controlled burning of a waste bale having $1.2 \mathrm{~m}$ diameter. The resulting estimate of the emission rate of toluene from the fire which was used in simulations is $190 \mathrm{~g} \cdot \mathrm{s}^{-1}$. The lifetime of toluene is estimated in [20] from several days to several months. Since for the considered problem the timescales of atmospheric transport are less than a few hours in simulations we neglect chemical removal of the pollutant.

As it is seen from Fig. 5, despite the greater distance to the point of interest (Kharkivsky District) of the waste landfill as compared to incineration plant, landfill fire has a greater influence on concentrations in the studied region than incineration plant due to ground-level release as com- 

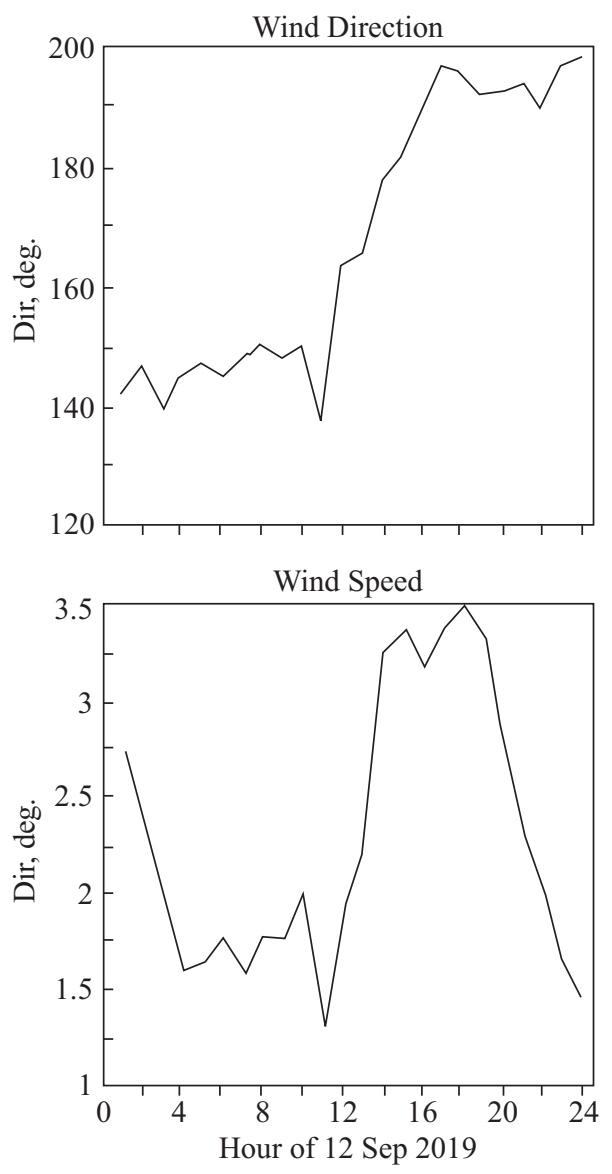

Fig. 7. Time plot of wind direction and speed in Kharkivsky district during September 12, 2019, according to simulations of the WRF-Ukraine numerical weather prediction system

pared to elevated release from incineration plant. The time-plot of concentration in the point of interest (Fig. 6) reveals a strong diurnal dependence of concentration. It reaches a maximum during the night because of surface inversions which existed during this time due to very calm and dry weather. The resulting concentrations during the night and morning of September 12, 2019, could reach up to $1.3 \mathrm{mg} \cdot \mathrm{m}^{-3}$ exceeding the permissible limit for toluene $\left(0.6 \mathrm{mg} \cdot \mathrm{m}^{-3}\right)$. Without taking into account emission from fire, due to emission from the incineration plant only, the maximum calculated concentration at the territory of Kharkivsky District is almost twice less $\left(0.7 \mathrm{mg} \cdot \mathrm{m}^{-3}\right)$. In the afternoon according to simulations of WRF-Ukraine numerical weather prediction sys- tem wind changed direction from SSE to SSW (Fig. 7) and therefore concentration in Fig. 6 rapidly decreased to zero. The accuracy of the presented results regarding maximum toluene concentrations is limited primarily by the available data on emission rate which is known within the factor of about 3 . The resulting confidence interval for the maximum concentration is estimated from 0.7 to $2.1 \mathrm{mg} \cdot \mathrm{m}^{-3}$.

\section{Conclusions}

The paper presents the results of the development of a web service for forecasting the dispersion of atmospheric pollution and its adaptation for use in the Cloud Computing Platform of the Ukrainian National Grid (UNG) infrastructure. In the course of the research, changes were made to the architecture of the web service to enable the running of the atmospheric dispersion model on the cloud computing platform. The developed web service is integrated into the e-catalog of services of the Virtual Center of Digital Science of UNG, which allows using of this service by interested and registered users. Further increase in the number of users requires certain upgrades in UNG infrastructure available to the developers. Presently with the developed service the forecast of air pollution is possible for every point at the territory of Ukraine. The service is accessible by the link: http://cloud-2.bitp.kiev.ua/airsystem english/airsystem_connect.html. The Terms of Use are available by the same link. The service is provided free of charge for registered users, but due to limited resources the Administrator approves applications of the new users when possible. The user can enter single or several sources together with the corresponding dates and release rates. The forecast is performed using the data of the WRF-Ukraine numerical weather prediction system and visualized in the form of maps and concentration time-plots through a web interface. The calculation for the historical periods is possible if data of WRF-Ukraine were stored for the corresponding period. The main advantages of the developed service over the ex- 
isting analogs are that: 1) the developed service uses detailed weather forecasts at the territory of Ukraine and thus the accuracy of air pollution forecast is increased as compared to products utilizing globally available weather forecast data; 2) it is based on technical solutions that utilize the capabilities of cloud computing infrastructure. Thus with a proper upgrade of the Cloud Computing Platform of the Ukrainian National Grid Infrastructure the system could be used by the increasing number of users. The implementation of the service in the UNG cloud platform is a necessary step towards its further integration into the EOSC. In future extensions we will also consider the possibility to extend calculations carried out by the web-service over the world.

The capabilities of the developed web-service were demonstrated by the example of simulation of air pollution in part of Kyiv affected by the releases from the incineration plant during pollution episode in September 2019. It was shown that measurements of toluene concentrations in exhaust gases reported in the literature for the incineration plant Energia could yield the emission rate of toluene from $130 \mathrm{~g} \cdot \mathrm{s}^{-1}$ to $430 \mathrm{~g} \cdot \mathrm{s}^{-1}$. For the considered period the fire on spontaneous waste landfill, which is located a few $\mathrm{km}$ from Kyiv, could also bring considerable amounts of pollutants to the studied region due to ground-level release and surface inversion. The resulting concentrations during the night and morning of September 12, 2019, could reach up to $1.3 \mathrm{mg} \cdot \mathrm{m}^{-3}$ exceeding the permissible limit for toluene $\left(0.6 \mathrm{mg} \cdot \mathrm{m}^{-3}\right)$. The accuracy of the presented results is limited primarily by the available data on the emission rate. The confidence interval for the maximum concentration is estimated from 0.7 to $2.1 \mathrm{mg} \cdot \mathrm{m}^{-3}$.

\section{Funding}

This work was partially supported with the project of the IT Development Program of the National Academy of Sciences of Ukraine Adaptation and Scaling of Web Services for Forecasting Weather and Air Pollution for Use in Cloud Infrastructure (Agreement No. 10305 dated 15.03.2019).

\section{Acknowledgements}

We acknowledge Dr. Sergiy Svistunov and Dr. Vitaliy Shadura from the Institute of Theoretical Physics of NAS of Ukraine for technical support during the integration of the developed service in UNG. We also thank the anonymous Reviewer for his valuable comments and suggestions.

\section{REFERENCES}

1. Kadaverugu, R., Sharma, A., Matli, C., Biniwale, R. (2019). High Resolution Urban Air Quality Modeling by Coupling CFD and Mesoscale Models: a Review. Asia-Pacific Journal of Atmospheric Sciences, 55, 539-556. doi: 10.1007/s13143019-00110-3.

2. Shavrina, A. V., Sosonkin, M. G., Veles, A. A., Nochvay, V. I., Blum, O. B. (2008). Integrated Modeling Of Surface And Tropospheric Ozone For Kiev City. In Simulation and Assessment of Chemical Processes in a Multiphase Environment (Eds. I. Barnes, M. M. Kharytonov). NATO Science for Peace and Security Series C: Environmental Security. Springer, Dordrecht. P. 345-356. doi: 10.1007/978-1-4020-8846-9 26.

3. Johnson, A. L., Abramson, M. J., Dennekamp, M., Williamson, G. J., Guo, Y. (2020). Particulate matter modelling techniques for epidemiological studies of open biomass fire smoke exposure: a review. Air Quality Atmosphere and Health, 13, 35-75. doi: 10.1007/s11869-019-00771-z.

4. Ma, S., Zhang, X., Gao, C., Tong, Q., Xiu, A., Zhao, H., Zhang, S. (2019). Simulating Performance of CHIMERE on a Late Autumnal Dust Storm over Northern China. Sustainability, 11, 1074. doi: 10.3390/su11041074.

5. Kim, G., Lee, M.-I., Lee, S., Choi, S.-D., Kim, S.-J., Song, C.-K. (2020). Numerical Modeling for the Accidental Dispersion of Hazardous Air Pollutants in the Urban Metropolitan Area. Atmosphere, 11, 477. doi: 10.3390/atmos11050477.

6. Kovalets, I. V., Romanenko, O., Synkevich, R. (2020). Adaptation of the RODOS system for analysis of possible sources of Ru-106 detected in 2017. Journal of Environmental Radioactivity, 220-221C, 106302. doi: 10.1016/j.jenvrad. 2020.106302.

7. Rolph, G., Stein, A., Stunder, B. (2017). Real-time Environmental Applications and Display sYstem: READY. Environmental Modelling \& Software, 95, 210-228. doi:10.1016/j.envsoft.2017.06.025. 
8. Kovalets, I. V., Maistrenko, S. Y., Khalchenkov, A. V., Zagreba, T. A., Khurtsilava, K. V., Anulich, S. N., Bespalov, V. P., Udovenko, O. I. (2017). Povitrya web-based software system for operational forecasting of atmospheric pollution after manmade accidents in Ukraine. Science and innovation, 13(6), 11-22. doi: 10.15407/scin13.06.013.

9. Scire, J. S., Strimaitis, D. G., Yamartino, R. J. (2000). A user's guide for the CALPUFF dispersion model (Version 5). USA, Concord: Earth Tech, Inc.

10. Skamarock, W. C., Klemp, J. B., Dudhia, J., Gill, D. O., Barker, D. M., Duda, M. G., Xiang-Yu, H., Wang, W., Powers, J. G. (2008). A description of the advanced research WRF version 3. NCAR Technical Note NCAR/TN-475+STR. USA, Boulder: National Center for Atmospheric Research.

11. Kovalets, I. V., Khalchenkov, O. V., Polonsky, O. O. (2019). Using the WRF-Ukraine system for forecasting agrometeorological conditions. Mathematical Machines and Systems, 1, 36-48 [in Ukrainian].

12. Zynovyev, M., Svistunov, S., Sudakov, O., Boyko, Y. (2007). Ukrainian Grid Infrastructure: Practical Experience. $4^{\text {th }}$ IEEE Workshop on Intelligent Data Acquisition and Advanced Computing Systems: Technology and Applications. (6-8 Sept. 2007, Dortmund, Germany). Dortmund: IEEE. P. 165-169. doi: 10.1109/IDAACS.2007.4488397.

13. Mell, P., Grance, T. (2011). The NIST Definition of Cloud Computing. Special Publication, 800-145. USA, Gaithersburg: National Institute of Standards and Technology. URL: https://nvlpubs.nist.gov/nistpubs/Legacy/SP/nistspecialpublication800-145.pdf (Last accessed: 28.05.2019).

14. Barclay, J. (2019). CALPUFF model, history and current status - part 1. Air Quality and Climate Change, 53(1), 8-9. URL: https://www.olores.org/en/techniques/dispersion-modelling/869-calpuff-model-history-and-current-status-part-1 (Last accessed: 28.05.2019).

15. SRTM3 Eurasia. URL: https://dds.cr.usgs.gov/srtm/version2_1/SRTM3/Eurasia/ (Last accessed: 28.05.2019).

16. Land-use USGS_LCI. URL: https://data.mint.isi.edu/files/raw-data/land-use/USGS_LCI/ (Last accessed: 28.05.2019).

17. Residents of the left-bank part of Kiev suffer from the stench at night. URL: http://kievvlast.com.ua/news/zhiteli-levoberezhnoj-chasti-kieva-zadyhayutsya-ot-voni-po-nocham (Last accessed: 28.05.2019).

18. Bezruk, Z. D., Porev, V. (2013). Study of the emission concentrations surface incinerator "Energy". Problems of Mechanical Engineering, 16(6), 37-42 [in Ukrainian].

19. Nammari, D. R., Hogland, W., Marques, M., Nimmermark, S., Moutavtchi, V. (2004). Emissions from a controlled fire in municipal solid waste bales. Waste Management, 24(1), 9-18. doi: 10.1016/j.wasman.2003.08.003.

20. Air Quality Guidelines for Europe (2 ${ }^{\text {nd }}$ Edition). WHO Regional Publications, European Series, No. 91. Copenhagen, Denmark: World Health Organization Regional Office for Europe, 2000.

Received 23.03.20

Revised 12.05.20

Accepted 16.06.20

Ковалець І.В. ${ }^{1}$, Майстренко, С.Я. ${ }^{1}$,

Халченков, О.В. ${ }^{1}$, Полонський, О.О. ${ }^{1}$, Донцов-Загреба, Т.О. ${ }^{1}$,

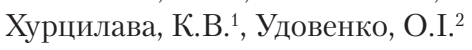

${ }^{1}$ Інститут проблем математичних машин та систем НАН України, просп. Глушкова, 42, Київ, 03187, Україна,

+380445263615, ik@env.com.ua

${ }^{2}$ Український центр екологічних та водних проектів, просп. Глушкова, 42, Київ, 03187, Україна,

+38 0445264518 , 1f@env.kiev.ua

АДАПТАЦІЯ ВЕБ-СЕРВІСУ ПРОГНОЗУВАННЯ

ЗАБРУДНЕННЯ ПОВІТРЯ ДЛЯ РОБОТИ НА ПЛАТФОРМІ

ХМАРНИХ ОБЧИСЛЕНЬ УКРАЇНСЬКОЇ

НАЦІОНАЛЬНОЇ ГРІД-ІНФРАСТРУКТУРИ

Вступ. Моделювання забруднення повітря є потужним інструментом, який дозволяє розробляти обгрунтовані рішення щодо зниження ризиків, спричинених викидами в атмосферу забруднюючих речовин.

Проблематика. Інфраструктури хмарних обчислень надають нові можливості щодо використання вебсистем прогнозування забруднень атмосфери. Реалізація цих можливостей потребує змін архітектури існуючих систем. 
Мета роботи. Адаптація вебсервісу прогнозування розповсюдження атмосферного забруднення в Україні для використання на платформі хмарних обчислень Української національної Грід-інфраструктури.

Матеріали й методи. Для дослідження обрано архітектуру вебклієнт - вебсервер - хмарні обчислення. Обчислення моделі здійснено у хмарній інфраструктурі, тоді як клієнтська і серверна частини функціонують на окремих комп'ютерах.

Результати. Розроблений сервіс дозволяє виконувати прогноз забруднення повітря для будь-якої точки на території України для більш ніж тридцяти речовин, зокрема й хлору, аміаку, сірководню тощо. Прогноз виконується 3 використанням даних системи чисельного прогнозування погоди WRF-Україна і візуалізується за допомогою вебінтерфейсу. Можливості розробленої системи було продемонстровано на прикладі моделювання забруднення повітря у вересні 2019 року у частині Києва, яка знаходиться у зоні впливу сміттєспалювального заводу «Енергія». Проаналізовано сумарні оцінки викидів толуолу від сміттєспалювального заводу та від пожежі на несанкціонованому полігоні відходів, розташованому в декількох кілометрах від Києва. Викиди від пожежі могли призвести до значного додаткового забруднення атмосфери досліджуваного регіону. Довірчий інтервал максимальної концентрації забруднення на той період оцінюється від 0,7 до 2,1 мг $\cdot \mathrm{m}^{-3}$, що перевищує нормативні значення $\left(0,6 \mathrm{m \Gamma} \cdot \mathrm{M}^{-3}\right)$.

Висновки. Розроблену систему можна використовувати в установах, відповідальних за оперативне реагування на екологічні аварії.

Ключові слова: забруднення повітря, атмосферна дисперсія, вебсистеми, хмарні обчислення. 